\title{
ANALYSIS OF INCOME COMPOSITION, ASSET QUALITY AND PROFITABILITY OF INDIAN COMMERCIAL BANKS
}

\author{
Deepa Pillai ${ }^{1}$ \\ Leena B. Dam ${ }^{2}$
}

DOI: https://doi.org/10.31410/ERAZ.2019.199

\begin{abstract}
Commercial banks are traditional financial institutions accepting deposits and lending whereby maintaining financial stability. Stability of the banking system and viability of banks is considered to be of principal significance growth of the economy. The shifting landscape of financial system has brought transition in the businesses of the banks along with rise in stressed asset levels. Quality of assets of bank directly affect the income, expense and balance sheet of the banks. The paper attempts to investigate the change in the income composition of banks further it also examines the change in the asset quality of banks over a period of 10 years. The research also aims to review the relationship between the asset quality and profitability of banks. Using a sample of public and private banks from India, a panel regression analysis affirmed the interrelationship between income, asset quality and earnings which indicates banks focus on nontraditional income has improved the quality of earnings, however higher credit to deposit ratio has declined the asset quality over the time span. Lower asset quality lead to lower return on assets and return on equity which confirms to the study by Lown and Friedman (1991) lower asset quality in economies defer economic recovery by decreasing operating profit margin and eroding capital base for new loans.
\end{abstract}

Keywords: Financial Stability, Asset Quality, Return on Asset, Income, Balance Sheet.

\section{INTRODUCTION}

well-developed financial intermediation is characterized by the stability in it banking sys-
tem channelizing surplus funds into savings for investment in productive activities leading to economic prosperity (King and Leven, 1993). Banks have been a fundamental participant in the financial intermediation process and financial stability through creation of loan assets; conversely, these loan assets exposed banks to numerous risk and liquidity restraints disturbing the profitability of banks and financial stability of the economy. Banks have come out of their customary role and ventured into new business practices for augmenting their margins at lower risks. Banking sector is a developed market tightly regulated and stable though it has become more competitive post liberalization as banks undertook risky behavior resulting into bank failures and financial crisis. Over the years multiple financial reforms have been initiated however these reforms resulted in extraordinary alterations in market structure, ownership patterns and financial operations of Indian commercial banks (Tzeremes (2015). The growing competitiveness among the various banking groups compelled banks to move away from traditional activities and to adhere the non-traditional banking activities. Banking literature indicates how transitions in the business have resulted in higher risk. Majority of literature supports that assortment of business is essential in a competitive environment, however some studies claim that increased risk behavior and deterioration in the asset quality is an aftermath of the com-

\footnotetext{
1 Symbiosis School of Banking and Finance, Symbiosis International (Deemed University), Maval Taluka, Mulshi, Pune - 412115, India

2 Global Business School and Research Centre, Tathawade, Wakad, Pune-33, India
} 
petition and change in business practices. Narashimham committee recommended the concept of Universal banking which encouraged banks to undertaken both commercial and investment activities. While the existing work discusses on the income diversification and asset quality, this paper examines how composition of income affect the asset quality and profitability of the banks whereby enhancing return to the shareholders.

\section{LITERATURE REVIEW}

\subsection{Income Diversification}

Generally, it is anticipated that rise in the share of the non-interest income of banks decreases the volatility in the profit margins as these incomes are not directly linked to the business environment. Study by (Demstez and Strahan 1997) and (Stiroh 2004) depicts doubt on the steadiness of profits and risk minimization of the banks through non-interest income similar studies can be conducted in Indian context to understand the underlying theory. When transition in the income composition takes place from interest income to non-interest income-based activities banks have to scale up their technology investments, hire skilled manpower, build additional capacity and increased capital expenditures. The effect of income diversification will vary across banks based on the product mix and ownership structure (Merecia et. al. 2007; Meslier et. al. 2014). Literature indicates two separate thoughts on the effect of income diversification, one where economies of scale and managerial competency are reactive factors of income diversification in banks, (Sanya and Wolfe 2011) contrary thought indicates that income diversification may dilute the comparative advantage of management increasing the volatility of profits. The financials of the banks indicate that change in the income composition by expanding businesses into non-traditional activities such as fees, commission and brokerage charges have enhanced the profits and the risk adjusted profits of the commercial banks over the decades. Private sector banks have scaled up the non-interest income through multiplicity of products and services offerings as compared to the public sector banks since liberalization. (Nguyen 2012) study enumerates no clear evidence of negative association between non-interest income and banks interest margins, however the study by (Lin et. al.2012) establishes interest margin shocks can be mitigated by non interest incomes. Non-traditional incomes of banks have shorter earning span as the switch over costs are low thus the challenge is in retaining the customer base (De Young and Roland 2001). In the Indian context limited studies can be found exploring the interlinkage between income diversification and profitability of banks. Studies indicate that there exists a tradeoff between soundness and profitability of Indian banks as non-performing assets erode the profits of the banks (Banerjee and Velamuri 2015). Study by (Pennathur et. al. 2012) depict that non-interest income has an impact on the profitability and risk measures of the banks. It was found that private sector banks had more income diversification as compared to the public sector banks which were reflective in the profits of the banks. Thus, the study tries to explore the income diversification in the Indian public and private sector banks and its effect on the profits and risk measures.

\subsection{Asset Quality and Risk}

Traditional understanding enumerates shift from interest to non-interest income results in risk minimization improving the risk return trade off (Stiroh 2004). There are conflicting predictions on the existing theories on banks engagement in non-traditional activities, some studies favor that fewer regulatory restrictions permit banks to take advantage of the economies of scale (Claessens and Klingebiel, 2001), whereas few studies comprehend that banks engaging in too 
many activities may lead to complex structures difficult to monitor and may lead to conflicting interests (Boyd et al., 1998). Global financial crisis had highlighted the issue of income diversification and bank risk. (Brunnermeier et. al. 2012) study indicate that higher non interest is subject to higher systematic risk, however study by (De Young and Torna 2013) evidences that non-interest income of banks is not explicitly risk increasing and concentrated banking system witness higher systematic risk; further, their study also proves that increase in non-interest income reduce the chances of bank failures. The financial soundness of the banks depends on the quality of its assets, higher rate of default has significant impact on the banks sustainability affecting the financial stability of the economy. Literature evidences that poor asset quality impacts the profitability of banks, however limited studies exist which measure the linkage between income diversification and profitability of banks with different asset qualities. Banks with higher loan default may have higher income diversification to offset the loan losses.

\section{DATA VARIABLES AND METHODOLOGY}

The data for the study is based on top five public sector and private sector commercial banks from India. The selection criteria for the banks were based top five banks from each sector having highest asset size. As the study evaluates the interrelationship between asset quality, income mix and return to equity shareholders, thus asset size of the banks becomes an appropriate measure for sample selection. Ten years data set has drawn from Capitaline to analyze the change in the income trends and asset size of banks over a period of 10 years' time. The main source of data comprises of income statement of banks, Balance Sheet of banks. In the dataset there are certain missing variables, therefore it is an unbalanced panel dataset.

\subsection{Definition of Variables}

i) Income composition

- The income composition of bank comprises of major two essential activities interest income and non-interest income. Interest income is derived for the assets whereas non-interest income comprises of fee-based income, income from trading activity and other miscellaneous income.

- The first set of indicators used for the study were the proportion of non-interest income to total income and interest income to the total income.

- A second set of indicators used for the study consists of Herfindahl indices. The indices measure the focus on the bank's income generating activities. For measuring the diversification of the income Herfindahl -Hirschman-index has been used to understand the concentration of other income.

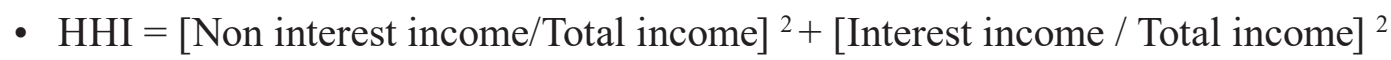

- Higher value of HHI indicates the business is concentrated on the interest income and lesser diversification in the business whereas lower value indicates higher diversification in the income for the banks.

ii) Asset Quality

- This section aims to explore the relation between noninterest income and profitability differs across banks with different asset qualities. Studies indicate that bank's loan portfolio quality has relationship with the non interest income. (Nguyen 2012) study enumerates that asset quality has a positive relation with the non interest income under varying timelines. There is a contradictory study (Tennant and Sutherland 2014) which 
indicates that there exist no association between the asset quality and the non interest income. The asset quality of the bank may or may not have an effect on the bank's noninterest income, however the rationale substantiates that these incomes enable the banks to absorb the losses occurring from the substandard quality of assets. Thus, a negative relationship can be interpreted between the loan loss and the non-interest income, simultaneously studies also prove that banks with large capital base would be in a better condition to absorb the loan losses.

iii) Profitability

- The profitability indicators selected for the study are Return on Assets and Return on Equity. Return on assets is an ideal proxy measure to evaluate the bank's profitability as the major business of the banks is loans and advances constituting major assets for the commercial banks. In isolation return on asset may be inadequate to arrive at conclusions, thus return on equity, net interest margin and net non-performing assets are considered to group the profitability indicators.

- We consider that the study will enrich the understanding of the determinants of non-interest income and its implications on bank risk and performance.

iv) Diversification in the asset composition

- Higher diversification in asset can be gauged from the ratio of non-interest-bearing assets in the bank's portfolio. The ratio is calculated as non interest assets to total assets. Higher diversification in the asset base results in risk mitigation for the banks.

Variable definition:

\begin{tabular}{|l|l|l|l|}
\hline Classification & Description & Variable & References \\
\hline Dependent Variable & & & \\
\hline Performance measure & ROE & Return on Equity & (Lee.et.al. 2014) \\
\hline Bank Diversification & ROA & Return on Assets & (Lee.et.al. 2014) \\
\hline & $\begin{array}{l}\text { Income diversifi- } \\
\text { cation }\end{array}$ & HHI & $\begin{array}{l}\text { (Stiroh, 2004) } \\
\text { (De Young and Roland 2001) }\end{array}$ \\
\hline & Net NPA & $\begin{array}{l}\text { Net non-perform- } \\
\text { ing assets }\end{array}$ & $\begin{array}{l}\text { (DeYoung and Rice, 2004; Stiroh 2004, } \\
\text { 2006) Lepetit, L., Nys, E., Rous, P., } \\
\text { Tarazi, A., (2008). }\end{array}$ \\
\hline
\end{tabular}

\section{RESULTS AND FINDINGS}

(Ramkrishnan and Thankor 1984) argued that diversification of income by banks increases banks credibility of overcoming information asymmetry while assessment of loan applications and monitoring of loans already approved. Studies also indicate that banks focus on only one area exploits the managerial competency and expertise of banks (Berger and Ofek 1996).

The first part of the study depicts the change in the business of commercial banks and asset size using trend over the specified time period. Both samples of public and private sector banks show sufficient heterogeneity in different types of banking activities, enabling us to analyze the behaviour of banks depending on their degree of product diversification. The table indicates the descriptive measures for all the banks and the individual group of banks. Over all the private and public sector banks average non-interest income are similar, however the composition of interest income of public sector banks is found to be higher which indicates concentration of credit as its main business activity. The non-performing assets of public sector banks are higher than the private 
sector leading to decline in profits and on return on equity reflecting the quality of its earnings. The information about earnings provides information of the bank's financial performance which is essential to decision making (Dechow and Schrand 2010). Manipulations in the earnings affects the banks stability, loan quality and the overall valuations (Beatty and Liao 2011), thus banks earnings quality becomes an important measure for assessing shareholders value.

\begin{tabular}{|c|c|c|c|c|c|c|}
\hline PUBLIC SECTOR BANKS & ROE & INT & NON-INT & NET NPA & HHI & ROA \\
\hline Mean & 8.13 & 66180.83 & 13786.22 & 17685.16 & 0.77 & 0.44 \\
\hline Median & 10.28 & 41774.75 & 5265.24 & 10393.58 & 0.78 & 0.60 \\
\hline Standard Deviation & 12.61 & 65168.56 & 19773.19 & 20822.54 & 0.06 & 0.69 \\
\hline Range & 59.61 & 236193.58 & 75088.54 & 110854.70 & 0.23 & 3.04 \\
\hline Minimum & -32.85 & 17128.56 & 2468.85 & 0.00 & 0.62 & -1.60 \\
\hline Maximum & 26.76 & 253322.14 & 77557.39 & 110854.70 & 0.85 & 1.44 \\
\hline \multicolumn{7}{|l|}{ PRIVATE SECTOR BANKS } \\
\hline Mean & 15.29 & 28682.01 & 12332.75 & 3188.28 & 0.63 & 1.52 \\
\hline Median & 16.31 & 23727.65 & 6982.88 & 1102.82 & 0.67 & 1.72 \\
\hline Standard Deviation & 5.33 & 20269.71 & 13418.19 & 5936.38 & 0.10 & 0.51 \\
\hline Range & 24.91 & 82918.14 & 56231.22 & 27823.56 & 0.29 & 2.02 \\
\hline Minimum & 0.11 & 2369.70 & 575.53 & 0.00 & 0.50 & 0.00 \\
\hline Maximum & 25.02 & 85287.84 & 56806.75 & 27823.56 & 0.79 & 2.02 \\
\hline
\end{tabular}

The table depicts the total sample summary statistics for the variables used in this study. While Panel A shows the summary statistics of all banks, Panel B and C show the summary statistics by ownership types. Public sector banks indicate higher proportion of nonperforming assets as compared to private sector banks, higher dispersion is observed in the spread of net non-performing assets with reduction in the shareholders returns. Higher concentration in interest income is seen for public sector banks with higher probability of credit risk evidenced through rise in the NPA levels of public sector banks.

In the second part of the study return on equity is regressed on income diversification, other income, return on assets and net non-performing asset values. Initially we tested the dataset for non-stationary in the variables. Phillips Perron Test has been used to check for non-stationary in the data. The hypothesis tested was that Non interest income, return on assets, return on equity and Net NPA has a unit root. At both levels and first difference the data were found to be stationery. Following which the data are analyzed at Original value (i.e. at Levels)

\begin{tabular}{|l|c|c|c|c|}
\hline Variables & Non-interest income & ROA & ROE & Net NPA \\
\hline $\begin{array}{l}\text { Phillip Perron test } \\
\text { Statistics }\end{array}$ & -10.45 & -5.3 & -5.9 & -6.97 \\
\hline p value & 0.00 & 0.00 & 0.01 & 0.01 \\
\hline
\end{tabular}

Two equations were derived one for private sector banks and other for public sector banks. Firstly, private sector banks ROE was regressed on non-interest income, return on assets, Net NPA and the diversification index. The table reflects the standardized coefficients and values representing $t$ statistics at $5 \%$ significance level.

The table indicates that return on equity is significantly affected by the interest income, non-performing assets and income diversification and return on assets. For public sector banks all the indicators are significant affecting the shareholders return highest being NPA and income diversification. Our study reaffirms that increasing emphasis on non-interest income increases profits of banks in the form of higher return to shareholders. 


\begin{tabular}{|lr|r|r|r|r|r|}
\cline { 2 - 7 } \multicolumn{1}{c|}{} & \multicolumn{3}{c|}{ Private Sector Banks } & \multicolumn{3}{c|}{ Public Sector Banks } \\
\cline { 2 - 7 } \multicolumn{1}{c|}{} & Coefficients & \multicolumn{1}{c|}{ Statistic } & P-value & Coefficients & \multicolumn{1}{c|}{ Statistic } & \multicolumn{1}{c|}{ P-value } \\
\hline Interest income & -0.00012 & -4.44229 & 5.92 & -4.13 & -0.56054 & 0.577956 \\
\hline Non-interest income & 0.00018 & 3.338314 & 0.001 & 0.00 & 0.36 & 0.71 \\
\hline Income diversification (HHI) & 37.12107 & 7.017926 & 1.08 & 8.99 & 0.247 & 0.805 \\
\hline Net NPA & -0.00014 & -2.02473 & 0.6 & -1.13 & -0.105 & 0.916 \\
\hline Return on Assets & 6.393446 & 9.097175 & 1.14 & 15.4 & 7.891 & 5.78 \\
\hline
\end{tabular}

\section{CONCLUSION}

It can be concluded that noninterest income does not contribute to asset quality or variability of banks' profits. Examination of the relationship between income diversification and bank profitability indicate that diversification increases the profitability whereas provisions lowers the profit and return on assets which supports the theory of concentration of business limits the profitability of bank business. However, private banks earn higher profits from increasing income diversity than the public sector banks. Furthermore, we find that banks that have lower asset quality, in terms of non-performing loans or loan loss provisions garner higher income diversification payback compared to the banks that have higher asset quality. Our findings are insensitive to another sample and to the measures of profitability and diversification of income. Nontraditional business activities enhance the margins for the banks particularly for the banks which have higher defaults or loan loss provisions. Other income could be one of the critical factors leading towards sustenance of banks in the long run erstwhile when the quality of loan portfolio is deteriorating.

\section{REFERENCES}

[1] Beatty, A., \& Liao, S. (2011). Do delays in expected loss recognition affect banks' willingness to lend? Journal of Accounting and Economics, 52(1), 1-20.

[2] Berger, Philip, Ofek, Eli, 1996. Bust up takeovers of value-destroying diversified firms. The Journal of Finance 51, 1175-1200.

[3] Claessens and Klingebiel, 2001, Competition and scope of activities in financial services, World Bank Res. Obs., 16 (2001), pp. 19-40

[4] Dechow, P., Ge, W., \& Schrand, C. (2010). Understanding earnings quality: A review of the proxies, their determinants and their consequences. Journal of Accounting and Economics, 50(2-3), 344-401.

[5] Demsetz, R. S., \& Strahan, P. E. (1997). Diversification, Size, and Risk at Bank Holding Companies. Journal of Money, Credit and Banking, 29(3), 300-313.

[6] J.H. Boyd, C. Chang, B.D. Smith, Moral hazard under commercial and universal banking, J. Money Credit Bank., 30 (1998), pp. 426-468

[7] J.R. Lin, H. Chung, M.H. Hsieh, S. Wu (2012), The determinants of interest margins and their effect on bank diversification: evidence from Asian Banks, J. Financ. Stab., 8 (2012), pp. 96-106

[8] Lepetit, L., Nys, E., Rous, P., Tarazi, A., (2008). The expansion of services in European banking: Implications for loan pricing and interest margins. J. Bank. Finance 32, 2325-2335.

[9] Markus Brunnermeier, Dong Gang, Darius Palia 2012, Banks' non-interest income and systemic risk, AFA 2012 Chicago Meetings Paper Available at SSRN: http://ssrn.com/abstract=1786738 or http://dx.doi.org/10.2139/ssrn.1786738 
[10] Nguyen, J. (2012). The relationship between net interest margin and noninterest income using a system estimation approach. Journal of Banking \& Finance, 36(9), 2429-2437.

[11] R. DeYoung, K.P. Roland 2001, Product mix and earnings volatility at commercial banks: evidence from a degree of total leverage model, J. Finance. Intermediation, 10 (2001), pp. 54-84

[12] Ramakrishnan, Ram, Thakor, Anjan ,1984. Information reliability and a theory of financial intermediation. Review of Economic Studies 51, 415-432.

[13] Robert DeYoung, Gokhan Torna (2013), Nontraditional banking activities and bank failures during the financial crisis, Journal of Banking and Finance, 22 (2013), pp. 397-421

[14] Stiroh, K. J. (2004). Diversification in Banking: Is Noninterest Income the Answer? Journal of Money, Credit, and Banking, 36(5), 853-882.

[15] Tennant, D., \& Sutherland, R. (2014). What types of banks profit most from fees charged? A cross-country examination of bank-specific and country-level determinants. Journal of Banking \& Finance, 49, 178-190 